\title{
Article
}

\section{Reconstructing the $26^{\text {th }}$ June, 1917 Samoa Tsunami Disaster and Implications on Present-day Hazard Exposure}

\author{
Laura Sischka ${ }^{1}$, Cyprien Bosserelle ${ }^{2}$, Shaun Williams ${ }^{2, *}$, Josephina Chan Ting ${ }^{3}$, Ryan Paulik ${ }^{2}$, Malcolm Whit- \\ worth ${ }^{1}$, Lameko Talia ${ }^{4}$, Paul Viskovic ${ }^{5}$ \\ 1 School of the Environment, Geography and Geosciences, University of Portsmouth, Portsmouth PO1 3QL, \\ UK; Laura.Sischka@myport.ac.uk (L.S.); Malcolm.Whitworth@port.ac.uk (M.W.). \\ 2 NIWA Taihoro Nukurangi, PO Box 8602, Ōtautahi Christchurch 8440, Aotearoa New Zealand; \\ Cyprien.Bosserelle@niwa.co.nz (C.B.); Ryan.Paulik@niwa.co.nz (R.P.). \\ 3 Disaster Management Office \& National Emergency Operations Centre, Ministry of Natural Resources and \\ Environment, Private Bag, Apia WS1338, Samoa; josephina.chanting@mnre.gov.ws (J.C.T.). \\ 4 Geosciences Section, Ministry of Natural Resources and Environment, Private Bag, Apia WS1338, Samoa; \\ lameko.talia@mnre.gov.ws (L.T.). \\ 5 GNS Science, Avalon, Lower Hutt 5011, Te-Whanganui-a-Tara Wellington, Aotearoa New Zealand; P.Vis- \\ kovic@gns.cri.nz (P.V.). \\ * Correspondence: Shaun.Williams@niwa.co.nz (S.W.)
}

\begin{abstract}
The $26^{\text {th }}$ June, 1917 tsunamigenic earthquake in Samoa is considered the largest historical event on record to have impacted this region in terms of earthquake magnitude and intensity. Yet, very little is known about the scale and distribution of tsunami impacts for this event compared with the recent 2009 tsunamigenic earthquake which originated in a proximal source region at the Northern Tonga Trench. In this paper, we reconstruct the 1917 tsunami from source to inundation using the BG-Flood numerical modelling suite to understand the magnitude of inundation for this event. Model outputs representing inundation extent and hazard depth intensities at spatially flexible grid resolution $(10 \mathrm{~m}, 20 \mathrm{~m}$ and $40 \mathrm{~m}$ ), are validated using available tide gauge records in Apia harbour and limited observations of runup that were derived from historical records. Results indicate variable modelled-to-observed consistency using available source models, wave and runup validation data. Significant discrepancies in recorded vs modelled wave arrival time at Apia of between 30-40 mins are observed, with modelled runup underestimated in southeast Upolu Island compared with the rest of the country where runup observations are available (e.g., west Savai'i Island). We combine the inundation model with available digital distributions of buildings and roads in the RiskScape multi-hazard risk analysis software, to produce exposure metrics for understanding the likely impacts on present-day coastal asset and population distributions if a similar tsunami were to occur. A comparison between the distribution of hazard risk exposure for the 1917 and 2009 events is discussed along with the uncertainties in our results, with suggestions for future work offered.
\end{abstract}

Keywords: coastal inundation; historical tsunami records; hazard exposure; impacts; BG-Flood; RiskScape

\section{Introduction}

More than 700 million people live in island states, most of them developing countries, and low-lying areas at the coast are under constant risk from tsunamis, storm surges or severe fluctuations of sea levels. In the Pacific, Small Island Developing States (SIDS) represent a collection of remote island communities with developing economies that are often at elevated risk from climate change, sea level rise, coastal erosion and both natural and anthropogenic hazards [1,2]. It is often the case that due to their geography and relatively small size of these islands, a significant proportion of the population, infrastructure and the commercial and industrial activity are concentrated in low lying areas, typically in a 
strip close to the coasts which render them at considerable risk from coastal inundation from tsunamis [3].

The central south Pacific region is frequently affected by tsunamis generated from earthquakes centred on the Tonga Kermadec Trench, including 39 events between 1837 and 2009 that included the 1917 and 2009 tsunamis that affected the Samoan islands [4]. These two nearly identical events suggest that tsunamis in this region are relatively common and as a consequence the SIDS in this area are exposed not only to global tsunamigenic events, but also to frequent locally derived tsunamis triggered by earthquakes, volcanic eruptions and submarine landslides [5]. Indeed, the recent submarine volcanic eruption of Hunga-Tonga Hunga-Ha' apai $(\mathrm{HTHH})$ in Tonga on $14^{\text {th }}$ January 2022 [6,7], and the resulting tsunami along with potential inferred predecessors (e.g., [8]), illustrate that there is a high degree of residual risk to these islands from local tsunami generating events.

Local tsunamis with less than 30 mins impact time are extremely hazardous to the island communities, due to the limited warnings and response times between the triggering event (earthquake or eruption for example), and the tsunami wave making landfall. Consequently, when trying to understand current tsunami risks and the nature and extent of exposure to these islands, it is common to use data or records from historical events to constrain the likely intensity (inundation extent and flow depths for example), and then use this within a scenario-based context to understand the present day exposure if such an event was to occur today. The focus of this study is to reconstruct the 1917 tsunami that struck the islands of Samoa, which was the second most deadly tsunamigenic event on record to affect this region after the fatal 2009 tsunami.

\section{Study Location and Historical Context}

Samoa consists of two main islands, Upolu and Savai'i, with several smaller in-habited and uninhabited islands between them (e.g., Manono and Apolima), as well as east and south of Upolu (e.g., Fanuatapu, Namu'a, Nu'utele, Nu'ulua and Nu'usafe'e) (Figure 1). Comprising part of a larger archipelago encompassing the geologically younger islands of American Samoa to the east, the island chain originated from hotspot volcanic activity and is fringed by coral reefs [9-11]. The geology of Samoa largely consists of mafic material (e.g., basalt and gabbro), due to its oceanic intraplate volcanic hotspot origins [12]. Savai'i is the bigger island with an area of $1,820 \mathrm{~km}^{2}$, whilst Upolu has an area of $1,114 \mathrm{~km}^{2}$ and accommodates over $67 \%$ of the total population of approximately 200,000 people [13]. Apia, the capital of Samoa, is located in the central north of Upolu.

In 1902 a temporary geophysical observatory was established in Apia on the then German administered island of Upolu, whereby it was initially set up to obtain baseline earth observations to compare with the British and German south polar expeditions of 1902-1903. Meteorological instruments and seismographs were installed in 1902 and magnetic instruments in 1905. These enabled studies into geomagnetism, seismology, meteorology, tidal variations and atmospheric electricity, and were so productive that in 1908 the observatory was established on a permanent basis.

In August 1914 troops of the New Zealand Expeditionary Force seized control of German controlled Samoa and the observatory. Its operations were much curtailed during the World War 1 (WW1) years but the German Director (G. Angenheister) continued observatory operations until it was formerly taken-over by the New Zealand government in 1921 [14-16]. New Zealand administration of the observatory continued until the handover in 1963 shortly after Samoa achieved political independence and control of the observatory. 


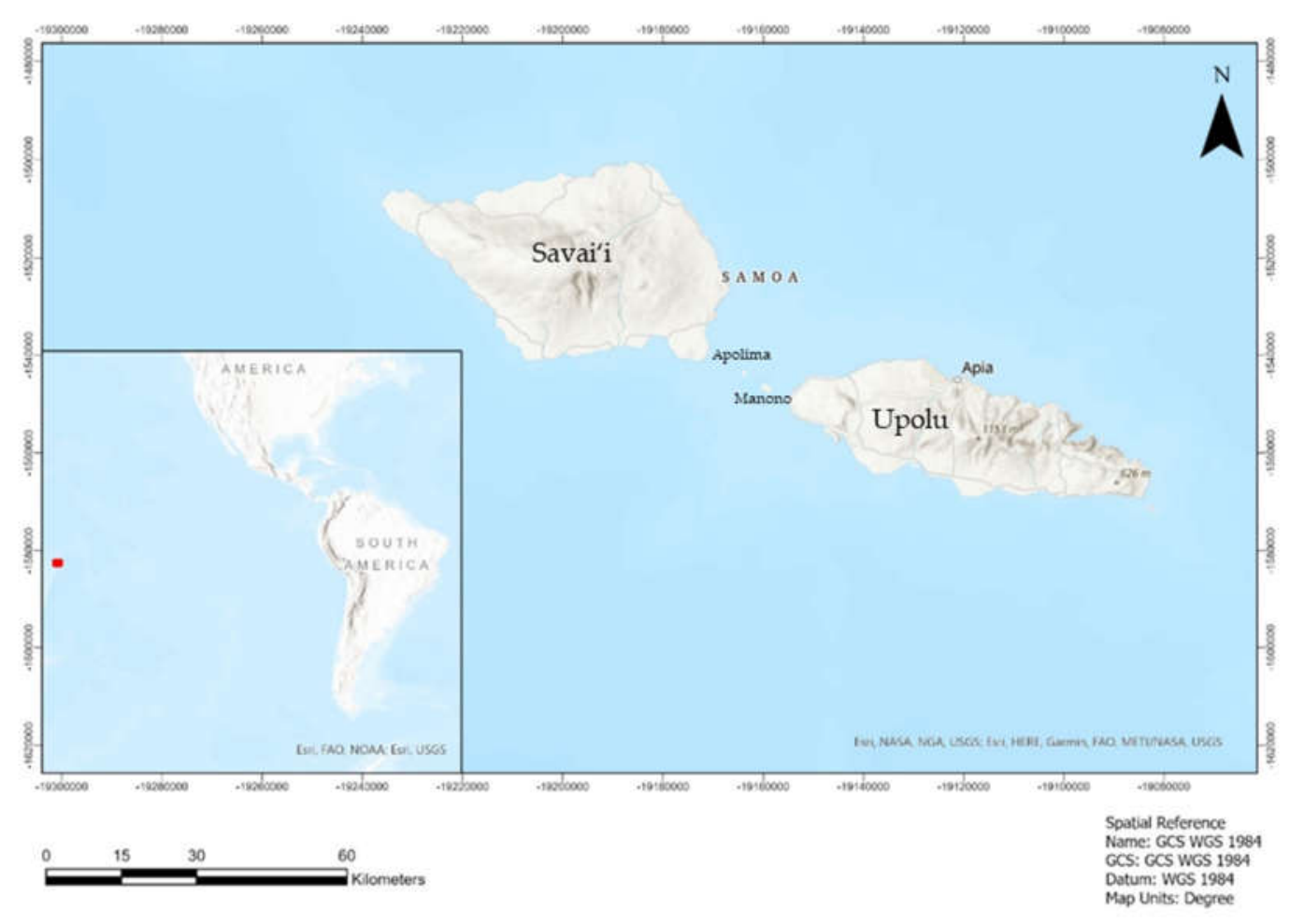

Figure 1. Location of Samoa showing the main inhabited islands.

Between 1917 to 1919 four tidal waves were recorded by the observatory on continuously recording tidal gauges that correlated with four earthquakes recorded by the seismograph installed at the observatory, with observations reported in [17].

Situated approximately $100 \mathrm{~km}$ north of the Tonga Trench, Samoa is exposed to a range of local geophysical hazards (e.g., earthquakes, volcanoes, landslides, tsunami). For example, the subaerial volcanic eruption from 1905 to 1911 on northeast Savai'i caused displacement / relocation of affected villagers to neighbouring Upolu [18], and generated several small tsunamis during this period with the most damaging occurring in 1907 [4]. Indeed, the recent 2009 complex earthquake sequence [19] and consequent tsunami which resulted in severe casualties and livelihood destruction in southeast Upolu reinforces this vulnerability [20,21].

The lesser known predecessor to the 2009 event, the $26^{\text {th }}$ June, 1917 UTC (local time in 1917 = UTC-11) earthquake and tsunami which originated in a proximal source region northwest of the 2009 epicentre (Figure 2), is arguably considered the largest earthquake to have occurred in this region in terms of magnitude (i.e., Mw 8.3 compared with Mw 8.1 for the 2009 earthquake sequence) [22-24]. However, the scale of impacts from the resulting tsunami appear to have paled in comparison with the devastation observed in the 2009 event (e.g., [25,26]). While anecdotal records indicate that the 1917 tsunami inundation had flooded several villages and caused damage to buildings and infrastructure (e.g., Satupaitea in southeast Savai'i and Lotofaga in southeast Upolu) $[4,27,28]$, there are virtually no accounts of any casualties. Available modern interpretations assume at least 2 people lost their lives based on generic descriptions of damage recorded after the event (e.g., [28]). Here, we use our inundation model for the 1917 tsunami along with present-day patterns of inundation exposure as a proxy to discuss and offer alternative views to help elucidate this enigma. 


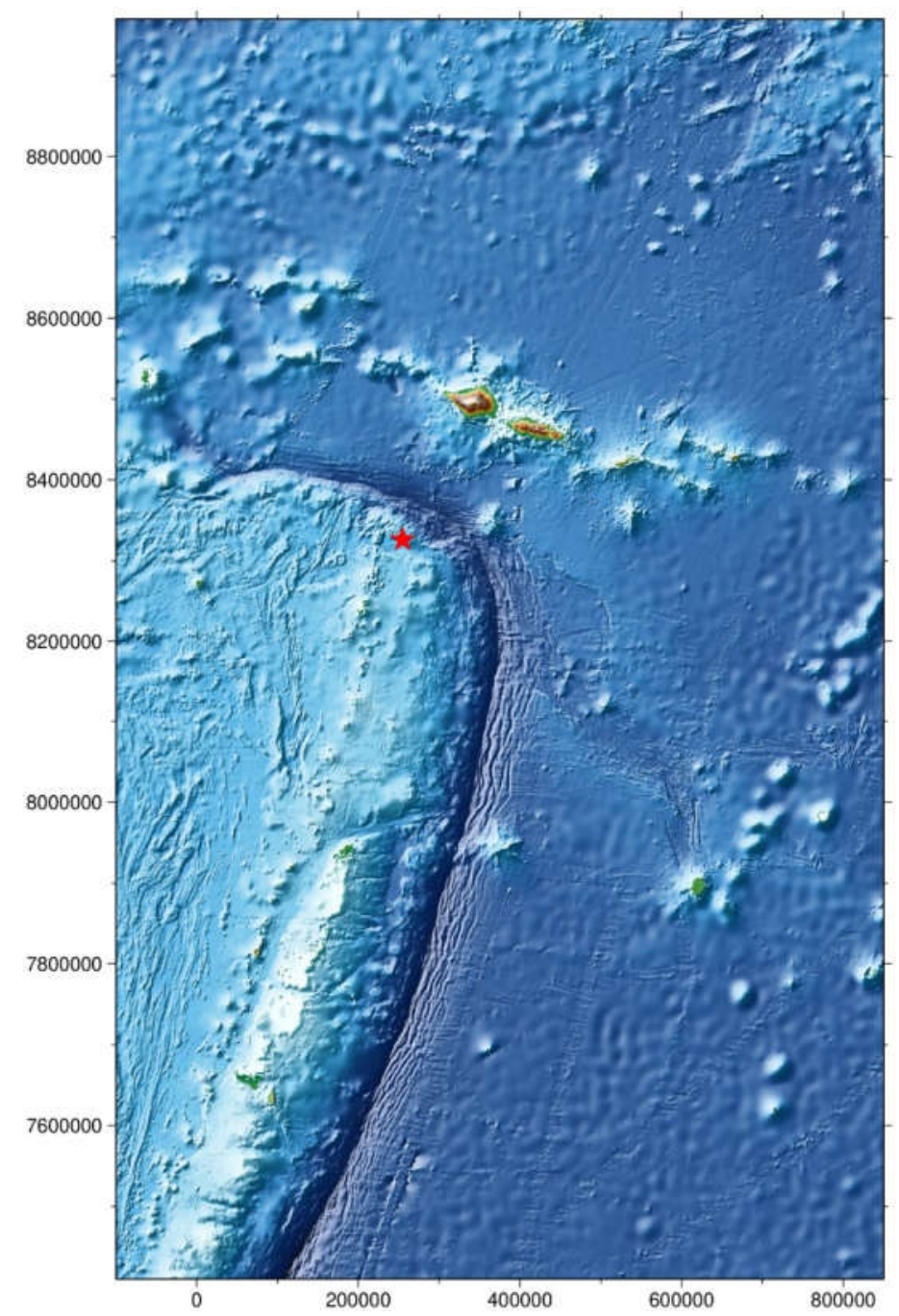

Figure 2. Location of the 1917 earthquake epicentre (star) relative to Samoa.

\section{Methods and Data}

The methods used in this study are described in two sections: 1) tsunami modelling which describes the process from the initial earthquake to the benchmarking process and inundation on land; and 2) tsunami exposure and damage analysis used in quantifying the hazard exposure on present-day buildings and population.

\subsection{Tsunami Modelling}

\subsubsection{Model Setup and Configuration}

This tsunami modelling analysis adapts a similar approach used by [21] to model the inundation of the 2009 event. For generation of the tsunami from the initial earthquake through to propagation and inundation, the BG-Flood software was used. BG Flood (Block-adaptive on Graphics processing unit Flood model) is suited for the simulation of flooding and/or inundation caused by rivers, rain, tides or tsunamis. It is based on the formulation of Basilisk as well as on the memory structure on the GPU of Block Uniform Quadtree of Vacondio et al. (2017) [29]. The block uniform quadtree structure enables various resolutions with the same memory size, but with different physical sizes [29].

For tsunami initialization, we used the earthquake parameters for the 1917 event presented by [25] to configure the source model. To start generating the initial earthquake, the following values were needed: fault parameters (strike, dip, rake, slip), the dimension 
of the rupture (length and width), the hypocenter of the earthquake (coordinates and depth) and the timing of the rupture. A rupture length of $150 \mathrm{~km}$ with a rupture width of $50 \mathrm{~km}$. The earthquake epicentre was located at $15.13 \mathrm{~S}^{\circ}$ and $173.28 \mathrm{~W}^{\circ}$ on the $26^{\text {th }}$ June 1917 at 05:49 UTC (i.e., $25^{\text {th }}$ June 1917 at 18:49 local time) at a depth of $10 \mathrm{~km}$. After applying vertical deformation to the fault, the initial water displacement was calculated as a theoretical visco-elastic fault displacement using the formulation of [30].

Figure 3 displays the water displacement after the 1917 earthquake. For the tsunami modelling, a fault length of $150 \mathrm{~km}$ was used to match the runup observations. As the model uses an adaptive grid (more than one resolution), three output NetCDF files were created with resolutions of $10 \mathrm{~m}, 20 \mathrm{~m}$ and $40 \mathrm{~m}$.

a

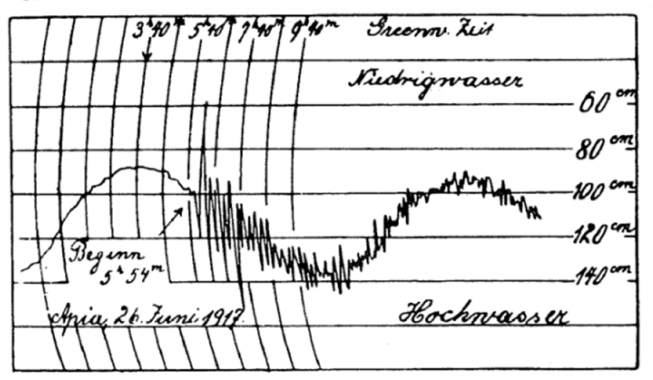

b

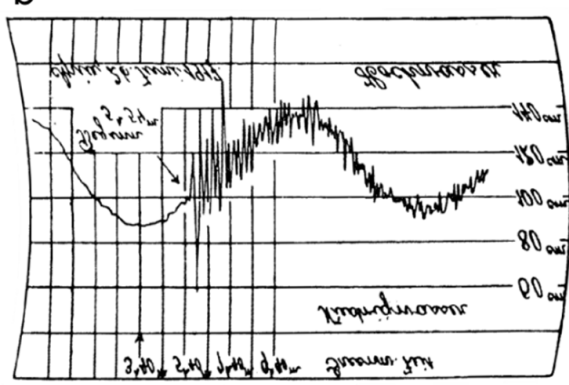

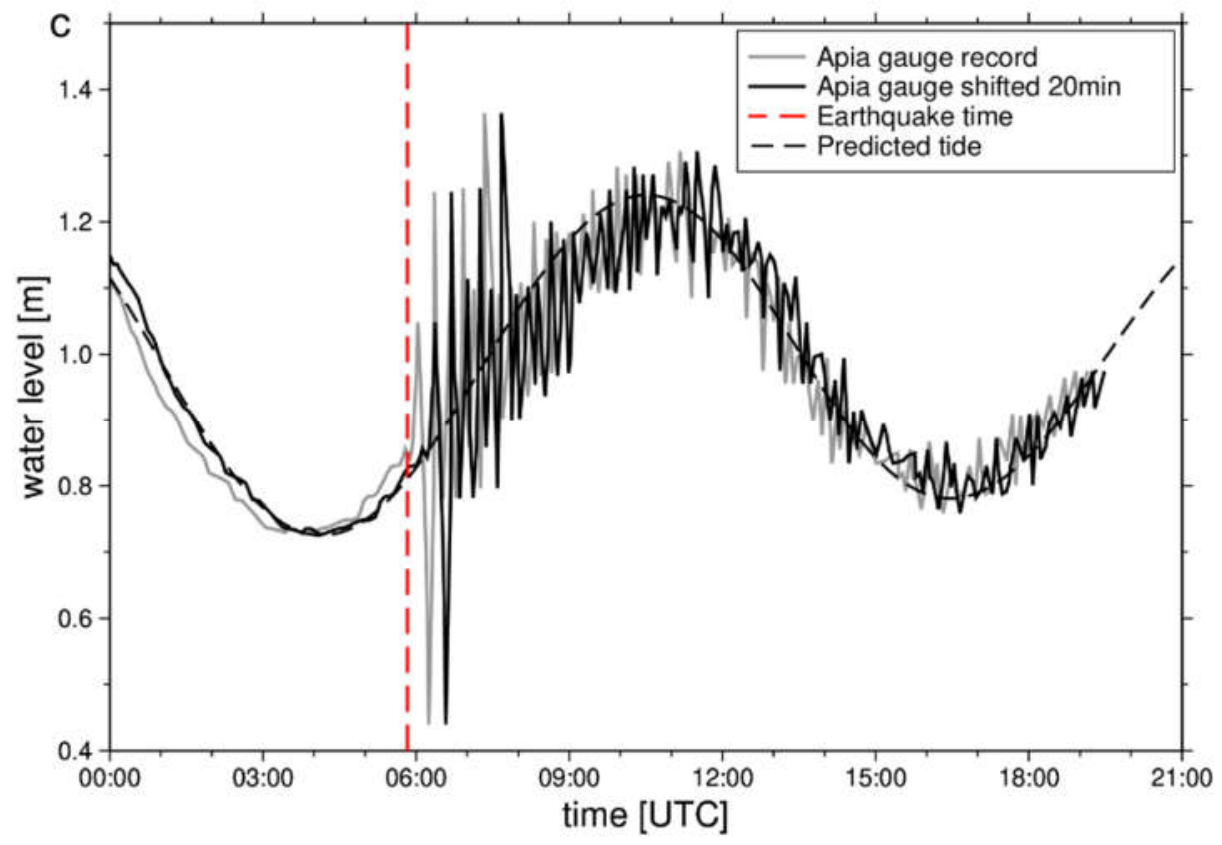

Figure 3. Tide gauge records for the 1917 tsunami in Apia harbour. (a) Original maregram [17]; (b) Inverted and reprojected maregram for digitization; (c) Digitized tide record (grey solid line) and predicted tide (black dashed line). The maregram shows the fluctuations of the sea in Apia harbour arriving only a few minutes after the earthquake. The earthquake occurred at 05:49 UTC (dashed red line), with the first noticeable sea level peak at 06:03 UTC. The maregram record prior to the earthquake better matched the predicted tide when shifting the record by 20 mins (black solid line), which also produces more consistent arrival time for the tsunami.

\subsubsection{Tide Gauge and Runup Observations}

Available tide gauge records from Apia harbour as well as runup observations from different parts of Upolu and Savai'i were used to validate the inundation modelling and subsequent assessment of present-day exposure and impacts in the runup zone. Tide gauge readings for the 1917 event measured in Apia harbour were digitized using the analog maregraph provided in [17]. The maregram in Figure 3 shows the fluctuations of 
the tsunami waves within the harbour. The digitized maregram generally matches the predicted tide at Apia (predicted by analysing tide constituent from recent tide record). However, the tide time reference given in [17] cannot be reconciled with an expected 3040 min travel time for the tsunami to reach Apia. Therefore, either the tide time reference or earthquake time/location is wrong. Moving the tide time reference given in [17] to 20 min later improves the correlation between predicted and measured tide and resolve the arrival time inconsistency. While there is no clear evidence to the authors that the tide time reference from [17] is wrong it appears the simplest explanation of the inconsistency It provides the first indication of the tsunami arrival time in Apia.

Runup observations derived from historical records of eyewitness accounts documented in $[4,26,27]$, provided benchmarks to infer the extent of wave runup onto land. These information were digitized to help validate the tsunami runup modelling.

\subsection{Tsunami Exposure and Damage Analysis}

\subsubsection{Building and Population Exposure Data}

Building objects on Savaii and Upolu that were located within the maximum tsunami inundation extent were remotely digitized from aerial and Google satellite imagery captured between 2016-2020. Buildings were manually digitized in GIS software, using roof outlines to create a vector polygon layer. Physical and non-physical attributes including use category and construction frame were assigned to each building object (Table 1). Samoan building construction frame typologies defined by [31] were attributed to features based on their size (i.e., outline area), roof shape and use category. In the absence of resources such as Google street view to visually validate use category and construction frame, these attributes were confirmed by local engineers and disaster risk management experts. The outline area $\left(\mathrm{m}^{2}\right)$ for confirmed buildings was calculated in GIS software.

Table 1. Summary of attributes represented in the building exposure data.

\begin{tabular}{ccc}
\hline Primary Attribute & Secondary attribute & Metric or Value \\
\hline Construction Frame & Masonry, Steel, Reinforced Concrete, Timber & Text \\
Usually-Resident Population & - & Floating \\
Outline Area & - & $\mathrm{m}^{2}$ \\
Use Category & Commercial; Community; Education; Fale; Hotel, Resort; Industrial; & Text \\
\hline
\end{tabular}

Samoa's usually-resident population was obtained from the 2016 national census [13]. Descriptive statistics for 'usually-resident population' at their residence on census day are aggregated and publicly available at national, district and village levels. Here, we apply usually-resident population at village levels $\left(V_{P o p}\right)$ to determine a residential building-object population rate $\left(B P_{\text {Rate }}\right)$ as follows:

$$
\begin{gathered}
V B_{\text {area }}=\sum_{j=1}^{n_{i}} B A_{i} \\
V B P_{\text {Rate }}=V P_{j} / V B_{\text {area }} \\
B P_{\text {Rate }}=V B P_{\text {Rate }} / B A_{i}
\end{gathered}
$$


where, $B A_{i}$ is the outline area $\left(\mathrm{m}^{2}\right)$ for a residential building located in village $j$, with $n_{i}$, the number of residential buildings within village $j . V B$ area is the total residential building outline area within village $j$. Residential building-object $V B P_{\text {Rate }}$ is the per $\mathrm{m}^{2}$ residential building population based on the usually-resident population $(V P)$ of village $j$.

\subsubsection{Building Fragility Model}

Fragility functions relate tsunami hazard intensity (e.g., flow depth) to the conditional probability of a building reaching or exceeding a given damage state [32]. Here, physical building damage is measured from empirical fragility curves representing Samoan buildings damaged in the 2009 SPT [31]. The fragility curves apply a cumulative lognormal function for 'timber', 'masonry' and 'reinforced concrete' construction frame buildings to determine the conditional probability (0-1) of "light", "minor", "moderate", "severe", and "collapse" damage states (DS) being reached or exceeded for a maximum tsunami inundation depth (Table 2). In the absence of representative fragility curves for some building typologies, 'masonry' curves are applied for 'steel' construction frame buildings while DS1 and DS2 fragility curves are applied for timber and reinforced concrete building typologies.

Table 2. Building fragility model parameters applied in this study.

\begin{tabular}{|c|c|c|c|c|c|c|c|c|}
\hline \multirow{3}{*}{\multicolumn{2}{|c|}{$\begin{array}{l}\text { Damage State } \\
\text { (DS) }\end{array}$}} & \multicolumn{6}{|c|}{ Construction Frame } & \multirow{3}{*}{ Damage Description } \\
\hline & & \multicolumn{2}{|c|}{ Timber } & \multicolumn{2}{|c|}{ Masonry } & \multicolumn{2}{|c|}{$\begin{array}{l}\text { Reinforced } \\
\text { Concrete } \\
\end{array}$} & \\
\hline & & $\mu$ & $\sigma$ & $\mu$ & $\sigma$ & $\mu$ & $\sigma$ & \\
\hline DS0 & None & \multicolumn{6}{|c|}{-} & None \\
\hline DS1 & Light & \multicolumn{2}{|c|}{-} & 0.29 & 0.46 & \multicolumn{2}{|c|}{ - } & Non-structural damage only \\
\hline DS2 & Minor & \multicolumn{2}{|c|}{ - } & 0.46 & 0.4 & \multicolumn{2}{|c|}{ - } & $\begin{array}{l}\text { Significant non-structural and } \\
\text { minor structural damage }\end{array}$ \\
\hline DS3 & Moderate & 1.15 & 0.38 & 1.28 & 0.35 & 1.38 & 0.56 & $\begin{array}{l}\text { Significant structural and non- } \\
\text { structural damage }\end{array}$ \\
\hline DS4 & Severe & 1.26 & 0.4 & 1.86 & 0.41 & 3.45 & 0.54 & $\begin{array}{l}\text { Irreparable structural damage, } \\
\text { will require demolition }\end{array}$ \\
\hline DS5 & Collapse & 1.62 & 0.28 & 2.49 & 0.4 & 7.3 & 0.94 & Complete structural collapse \\
\hline
\end{tabular}

\subsubsection{Tsunami Inundation Exposure and Damage Model}

A deterministic model is applied to quantify the present-day building and population exposure as well as damage from tsunami inundation. To this end we use RiskScape, an open-source software that provides a multi-hazard risk modelling framework for deterministic analysis of tsunami impacts [33]. Here, a deterministic model 'pipeline' is developed to analyze the exposure and damage based on the tsunami model, exposure inventory and fragility model components described in Sections 3.2.1 and 3.2.2. These components formed the 'input data' for the model pipeline used which sequences a series of steps and step-functions to sample and analyze deterministic tsunami impacts (Figure 4). 


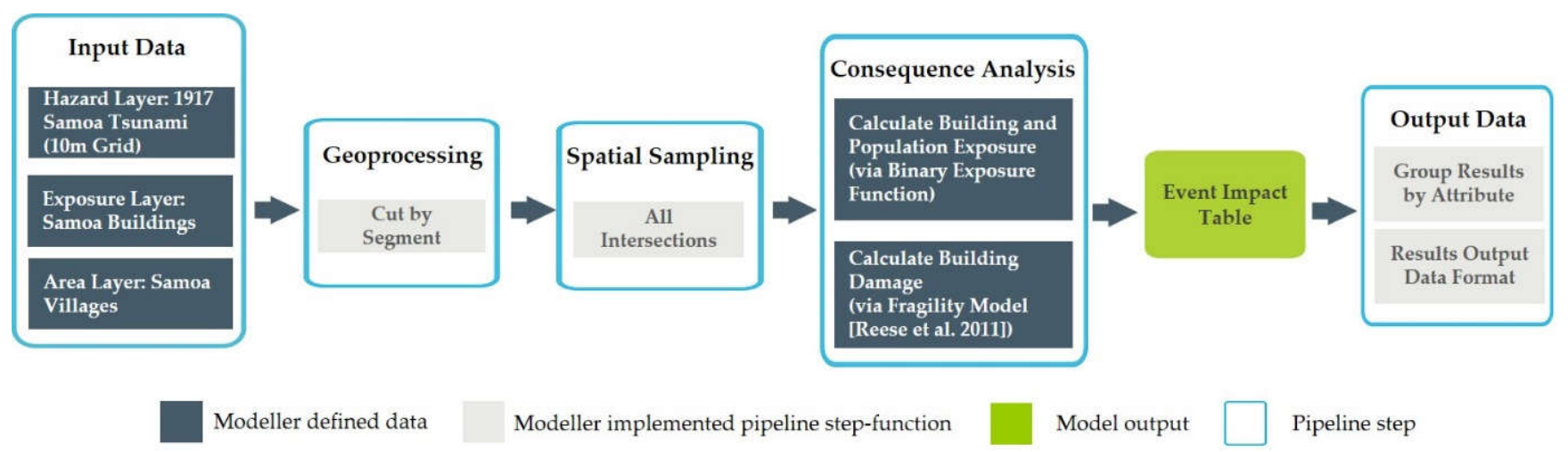

Figure 4. A schematic representation of the RiskScape model pipeline steps and functions applied in this study.

The 1917 event input hazard data layer represented at the adaptive grid resolutions $10 \mathrm{~m}, 20 \mathrm{~m}$ and $40 \mathrm{~m}$ were segmented using a geoprocessing step-function (i.e., 'cut by segment') to extract all tsunami inundation grid cells within the exposure data layer (building outlines). Extracted grid cells were then spatially sampled (i.e., 'all intersections') to determine the maximum inundation flow depth (MaxD) at each building location. The consequence analysis applies $\operatorname{Max} D$ to determine: 1) building and population exposure to tsunami inundation; and 2) building damage state. Individual building exposure (Bldexp) to inundation is quantified using a simple binary function:

$$
B_{\text {exp }}= \begin{cases}1, & \operatorname{MaxD}<0 \mathrm{~m} \\ 0, & \operatorname{MaxD} \geq 0 \mathrm{~m}\end{cases}
$$

When inundation is present or not at a building location, the corresponding binary value is assigned to the building in the 'event impact table' (EIT). Where inundation is not present (i.e., ' 0 '), no damage (DS0) is assumed. Where inundation is present (i.e. ' 1 '), conditional probability (i.e., $0-1$ ) of damage states DS1 to DS5 based on fragility curves from [31] is calculated in response to the independent variable MaxD. Fragility curves coded in python using nested statements apply a lognormal function for each curve based on the dependant variables shown in Table 2 for the corresponding building construction frame in Table 1 . The conditional probability determined from each fragility curve is then reported in the EIT for each building exposed to tsunami inundation.

The resulting EIT contains tsunami exposure and damage information for model output reporting. In this study the EIT includes attributes, hazard intensity (i.e., MaxD), exposure (i.e., Bldexp) and damage state information for each building object. The 'output data' pipeline step-function 'group results by attribute' is applied here to report descriptive statistics of model results. Building 'count' and population 'sum' exposure to tsunami inundation is enumerated and reported at national and village scales, and by hazard intensity (flow depth) bins of $0.5 \mathrm{~m}$. Building damage states are also reported by building count for 0.1 conditional probability bins between 0 and 1 . The step-function 'results output file format' outputs this information as spatial file formats (e.g., GIS shapefile, commaseparated value) for national and sub-national spatial analyses of present-day building and population exposure, as well as damage to the 1917 tsunami event.

\section{Results}

\subsection{Tsunami Inundation and Validation}

Figure 5 shows the modelled maximum tsunami wave heights for the 1917 tsunami event. Of particular note is that the southwest side of Savai'i is mostly affected where wave heights of $2 \mathrm{~m}$ appear to have impacted the coast. Interestingly, the arrival of the 
simulated wave in Apia harbour suggests that it took approximately 34 mins travel time to this location. This is consistent with the observed tide gauge record (Figure 6) when using a 20 mins shift in the reference time.

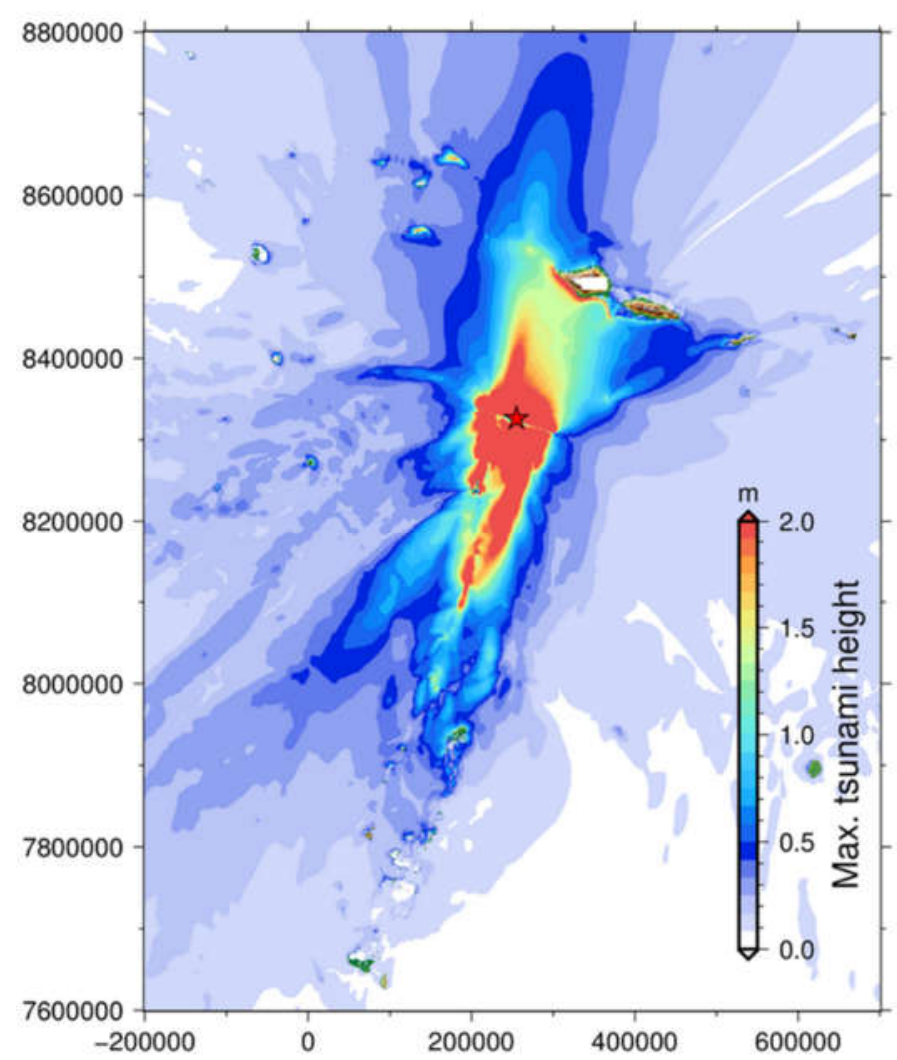

Figure 5. Maximum wave height offshore for the modelled 1917 tsunami.

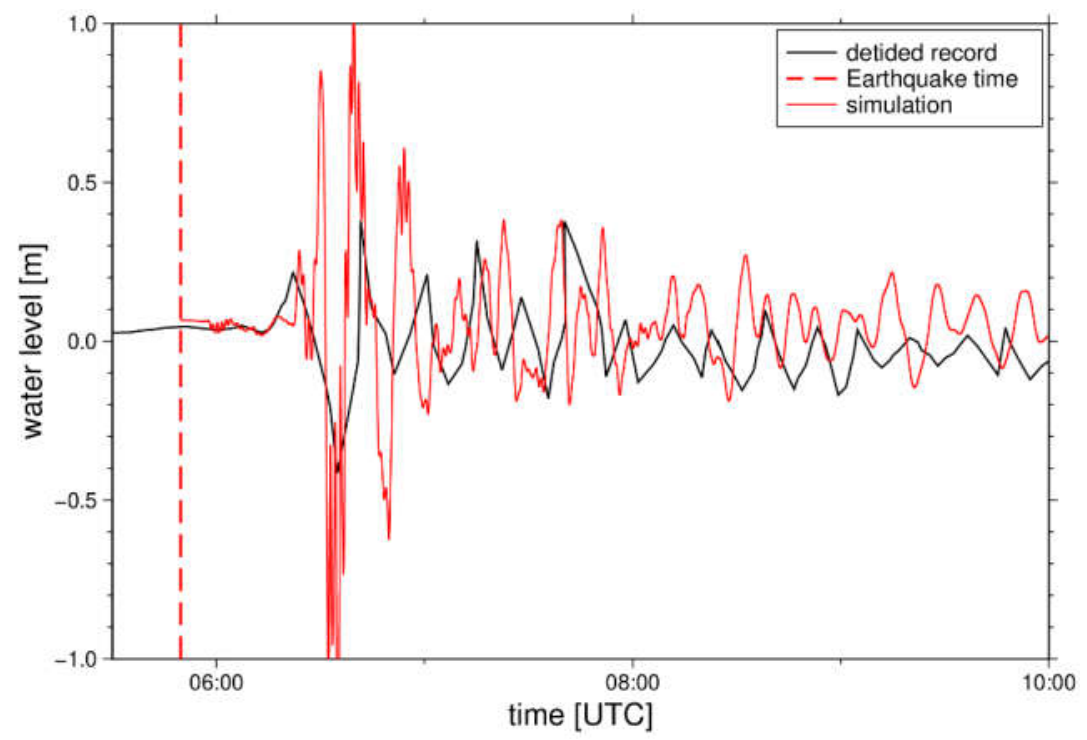

Figure 6. Detided water level recorded in Apia (black line) and simulated (red line). Earthquake time is also given

Figures 7 and 8 show which parts of Upolu and Savai'i are most affected by the tsunami. Inundation on Savai'i mostly affects the south western side of the island with much higher flow depths compared with eastern parts of the island including Upolu. Northern 
Upolu appears unaffected except in areas near Apia. Observed runup points derived from historical records identified in Savai'i (Figure 7) and Upolu (Figure 8) highlight the limited runup observations available for this event.

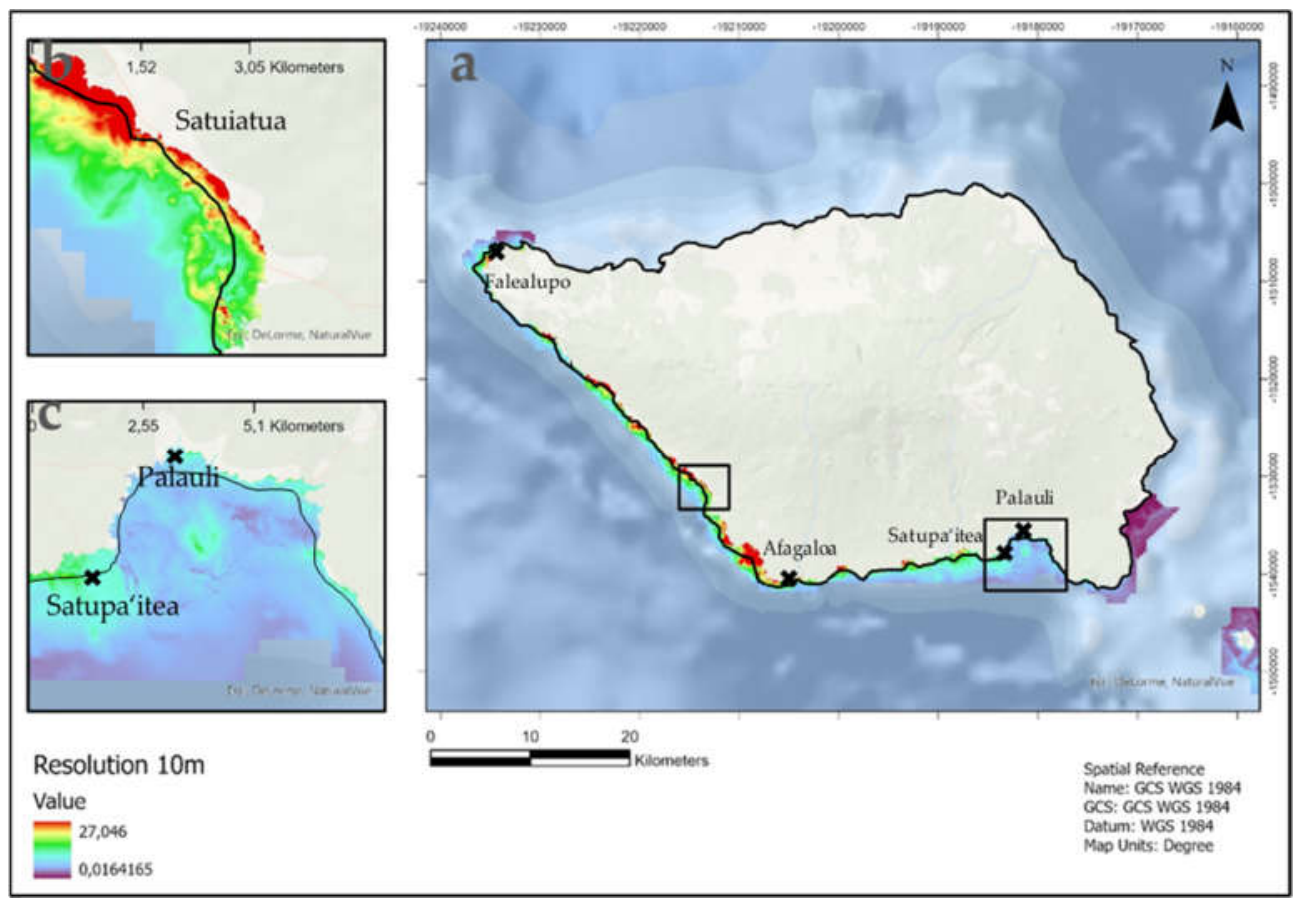

Figure 7. Inundation on Savai'i in close-ups (10 $\mathrm{m}$ horizontal resolution). The map shows the $10 \mathrm{~m}$ resolution run-up on Savai'i (a) and close-up of inundation in Satuiatua (b), and in Palauli and Satupa'itea (c).

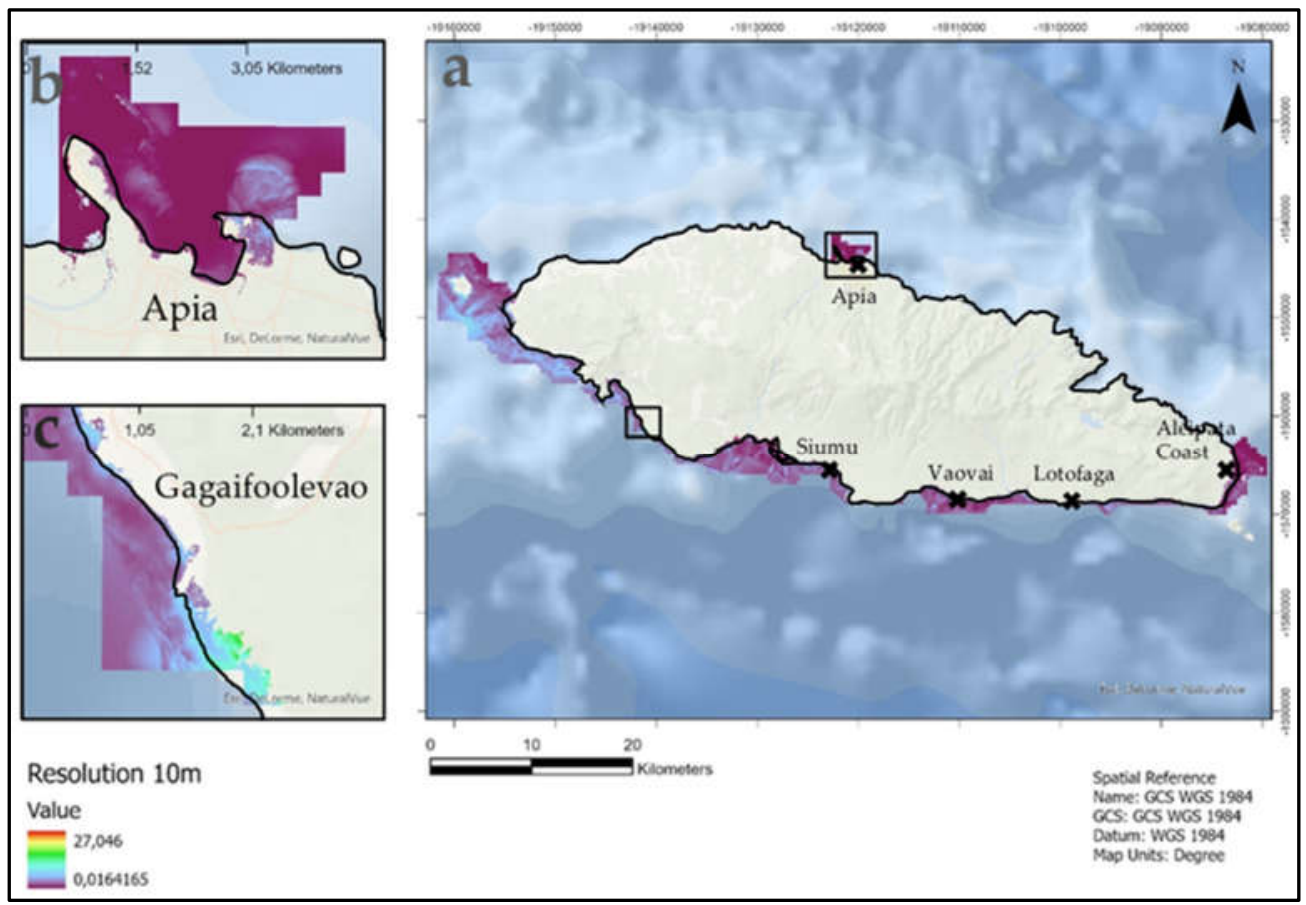

Figure 8. Inundation on Upolu in close-ups (10m res.). The map shows the $10 \mathrm{~m}$ resolution run-up on Upolu (a) and in Apia (b), with the most severe inundation in Upolu close to Gagaifo'olevao (c). 


\subsection{Damage to Present-day Buildings and Population Exposure}

If a characteristic 1917-tsunami event scenario were to occur in the near future, we estimate that approximately 2,295 buildings would be affected by the inundation (based on present-day building stock). Most exposed buildings on both Savai'i and Upolu are subjected to flow depths $>0.0 \mathrm{~m}$ to $\leq 0.5 \mathrm{~m}$ (Figure 9). As flow depth increases, the number of buildings in each category decreases. However, it is worth noting that 206 buildings on Savai'i are exposed to flow depths $>3.0 \mathrm{~m}$, which generally means these buildings are most likely to experience moderate to severe damage. Construction frames made of timber have a higher probability of suffering from severe damage or undergo complete collapse (Figure 9b).

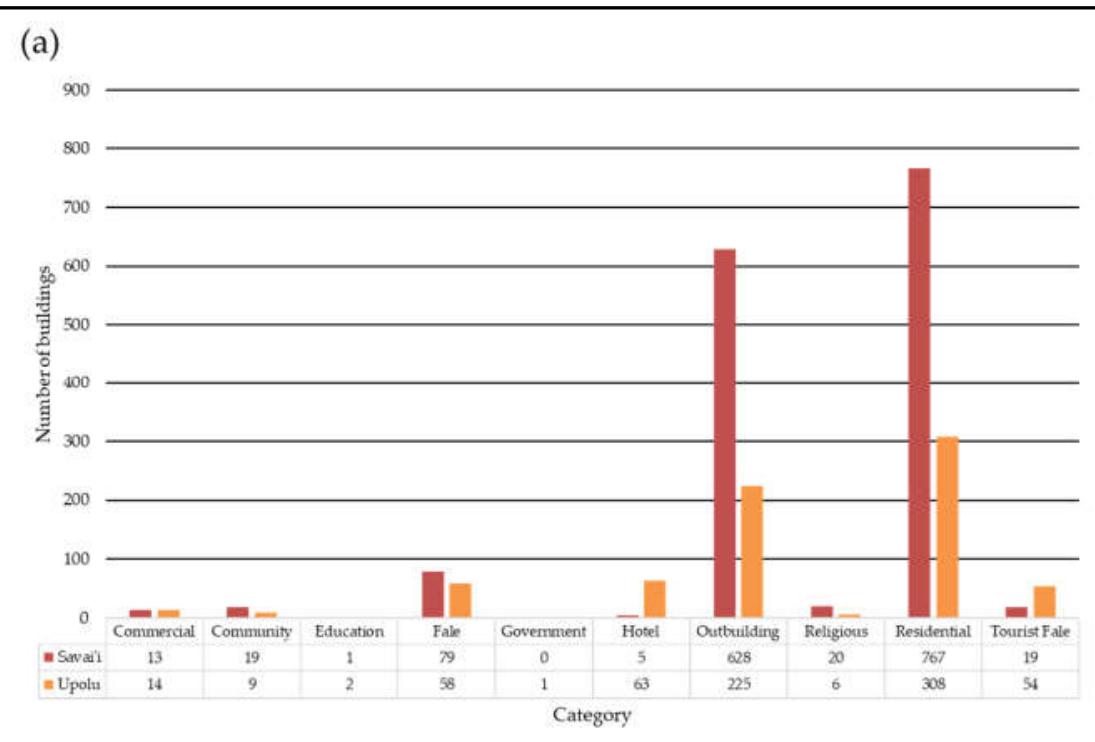

(b)

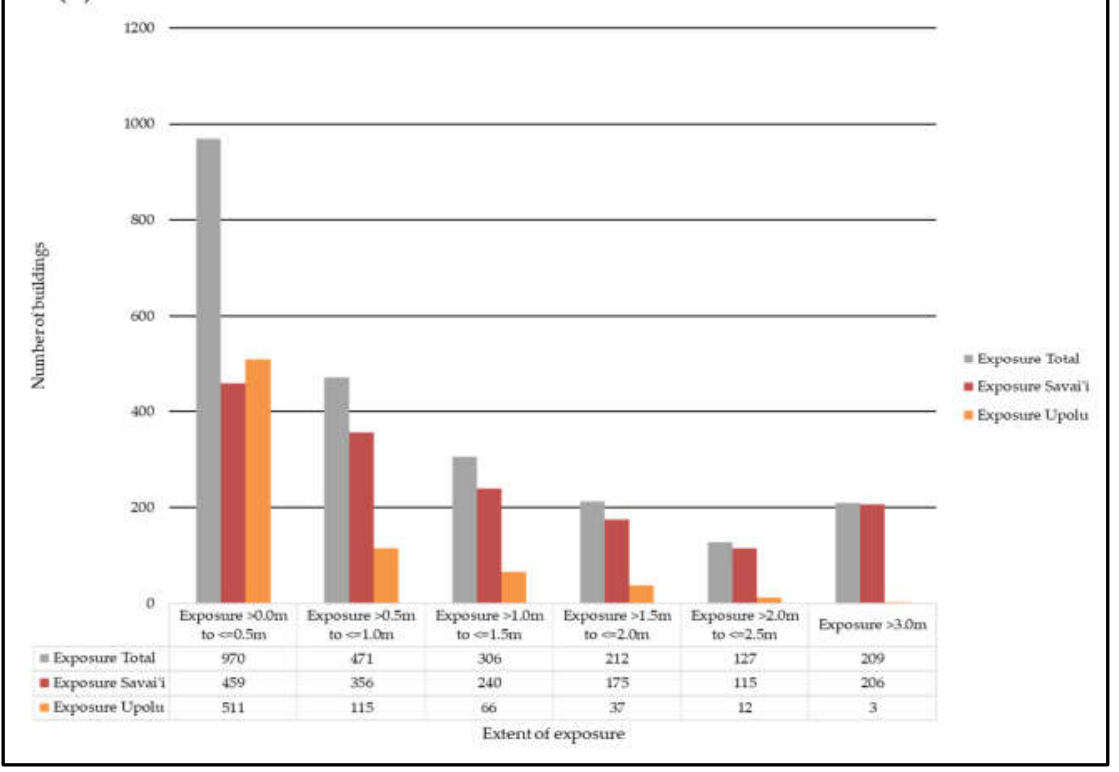

Figure 9: (a) Present-day buildings categories on Savai'i and Upolu. (b) Exposure of buildings in Savai'i and Upolu to the 1917 modelled scenario event

The total number of people living in residential buildings within the modelled 1917 tsunami inundation zone are exhibited in Figure 10. In total approximately 7,919 people 
across 1,074 residential buildings ( $71 \%$ of which are in Savai'i), would be affected by the tsunami which amounts to approximately $4 \%$ of the total population in 2016 [34].
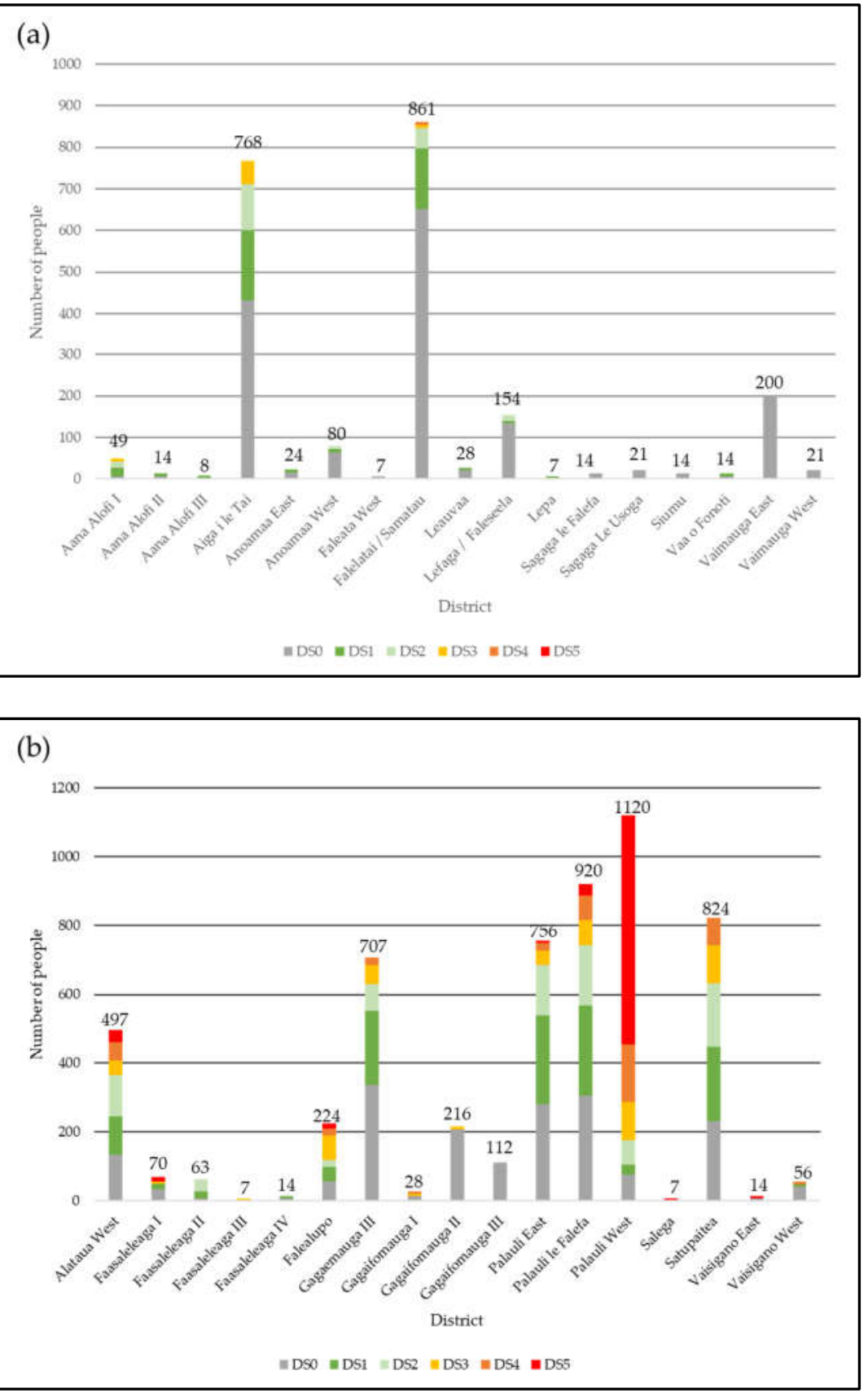

Figure 10: Number of people affected in residential buildings in the 6 damage states on: (a) Upolu, and (b) Savai'i.

It is worth noting that on Savai'i $13 \%$ of the affected inhabitants live in buildings which are estimated to sustain damage states of DS5 (i.e., complete building collapse). This is particularly the case for the district of Palauli West. On Upolu, more than half of the affected population live in buildings estimated to sustain damage states DS0 (i.e., no damage). The more inundated part of Upolu in the west of the island exposes approximately 77 people who live in buildings likely to sustain damage state DS3 or greater. 


\subsection{Comparison with the 2009 tsunami}

The 2009 event is the most devastating tsunami to have affected Samoa in recent history. Occurring on the $29^{\text {th }}$ of September, at 06:48 am local time, two earthquakes only minutes apart shook the ground and caused large waves travelling quickly through the ocean which caused major destruction and loss of life in less than 30 mins after the earthquake rupture [19]. As the 1917 event can be considered a historical predecessor to the 2009 event in terms of source region, a comparison between the two events is made.

The main differences between the 1917 and 2009 events in terms of the distribution of affected coast are highlighted in Figure 11. The main energy beam for the 1917 tsunami was focused towards west and south Savai'i while for the 2009 event, energy was focused towards American Samoa and southeast Upolu, which reflects the proximal epicentral locations of the generating earthquakes, respectively, which were about $150 \mathrm{~km}$ apart.

Of particular note is the time of day in which each event occurred. Both events occurred either in the morning (2009 tsunami) or in the evening (1917 tsunami) during times when residential population were not at maximum capacity. Had each event occurred in the middle of the night, for example, then the scale of human losses might have been significantly greater for each event.

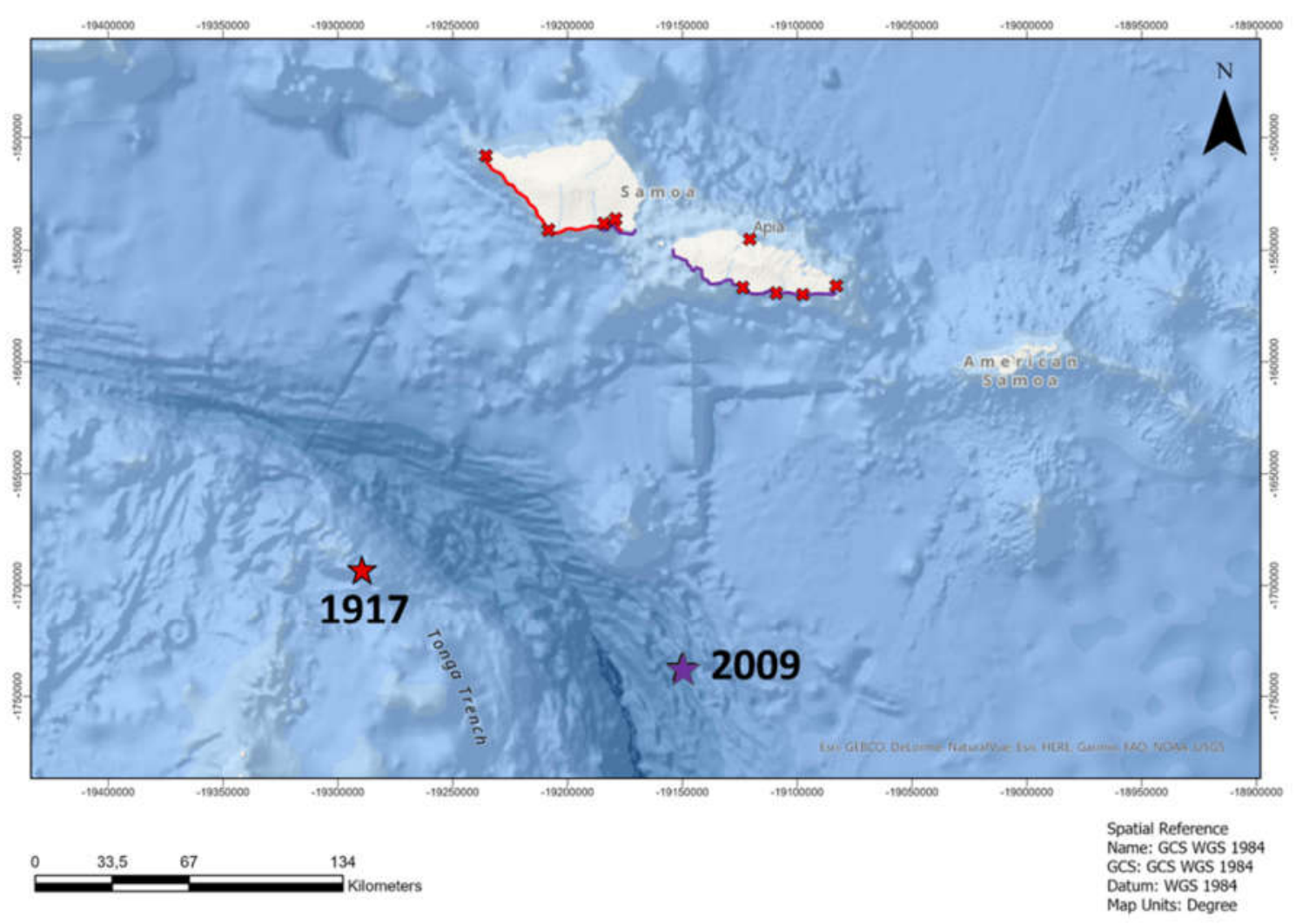

Figure 11. Epicentres of the 1917 and 2009 earthquakes and corresponding extents at coast which were predominantly affected by each respective tsunami according to the models. The red crosses indicate the 1917 runup benchmarks shown in Figures 6 and 7 showing locations which should be inundated.

\section{Discussion}

Our results suggest that the south coast of Savai'i including parts of south Upolu were affected by the 1917 tsunami. A comparison of the historic evidence with the modelled inundation shows some inconsistencies. For example, observations of runup in the village of Lotofaga in southeast Upolu indicate that half of the village was submerged 
$[4,27]$, which suggests significantly greater inundation extent and flow depth in Lotofaga than what our model reproduces. That is, the modelled inundation suggests that Lotofaga was not severely impacted. This inconsistency likely reflects the simplicity in our tsunami source model in the light of recent evidence of complex behaviour at 'subduction-zone bends' as is the case at the northern Tonga Trench [19].

In addition, records of the maregram of Apia harbour indicated initial water level fluctuations only 5-10 mins after the earthquake compared with approximately 34 mins modelled wave arrival time in Apia. The observed fluctuations of 5-10 mins in Apia after earthquake initiation is highly unlikely if considering that the tsunami was generated/influenced by the earthquake source alone, which was located further west of the 2009 epicentre and farther away from Apia. On the other hand, the maregram accurately recorded the normal tides at the time of the event which were within 14 mins of tide predictions, which suggests that either the timing of the tsunami record or the earthquake timing is wrong or more complexity in the tsunami source mechanism than what is currently captured in our modelling. It is probable that the earthquake could have caused co-seismic submarine landsliding close to or along the north coast of Upolu which might explain the early fluctuations observed in Apia harbour which cannot be accounted for using a simplistic earthquake source mechanism alone (e.g., [35]). However, further investigations are needed to unravel this dilemma.

Nevertheless, the hazard risk patterns compared with the 2009 event indicate that the 1917 tsunami was more severe on the island of Savai'i compared with Upolu. However, the absence of verifiable records pertaining to loss of life in the 1917 event suggest that either: 1) inundation from the 1917 event, on balance, was less destructive than the inundation caused by the 2009 event; 2) the occurrence of the 1917 in the evening meant that people who felt the earthquake shaking might have been more aware of the potential tsunami threat and self-evacuated minimizing loss of life or injuries; or 3) potential casualties from this event were simply not accurately reported/documented. The latter reflects postWW1 colonialism in Samoa in 1917 where it is generally accepted that reported accounts were not accurately depicted (an example of this is the significant mis-representation of post-colonial population decline in Samoa of $80-90 \%$ compared with previous estimates of $20-50 \%$ [36]).

\section{Conclusions}

This study aimed to reconstruct the 1917 tsunami in Samoa and assess the impacts of inundation on present-day buildings and population exposure. Our findings show variable consistency between modelled-to-observed event reconstructions, which are exemplified by inconsistency in the wave arrival time in Apia and underestimation of inundation extent/intensity in southeast Upolu. The observed discrepancies are probably due to: 1) earthquake source model and geometry configuration; 2) instrumental seismic and/or tide gauge record uncertainties for Samoa in 1917 which might explain the 20 mins anomaly in the tidal reference time; 3) limited records of runup observations for validation; 4) uncertainties in potential co-seismic mechanisms which might have exacerbated the observed characteristics of the tsunami (e.g., in Apia harbour).

Notwithstanding these discrepancies, our modelling provides a first-order estimation of the scale and magnitude of the 1917 tsunami inundation in Samoa for use in scenario-based hazard risk assessment. Comparison between the 1917 and 2009 events suggests that the extent of exposure distribution around the two main islands of Samoa from local tsunamis originating at the Northern Tonga Trench is highly influenced on the earthquake epicentre and location/orientation of co-seismic displacement. That it, Savai'i Island is more exposed to tsunamis originating along the western segment of the NTT (e.g., 1917 event), compared with Upolu in the east which exhibits greater exposure to outer-rise events originating along the east NTT segment. 
Author Contributions: Conceptualization, L.S., C.B., S.W., R.P., J.C.T., M.W., L.T. and P.V.; methodology, C.B., S.W., R.P. and L.S.; software, C.B., R.P., L.S., S.W. and M.W.; validation, L.S., C.B., S.W., R.P., J.C.T., M.W., L.T. and P.V.; formal analysis, L.S., C.B., S.W., R.P., J.C.T., M.W., L.T. and P.V.; investigation, L.S., C.B., S.W., R.P. and P.V.; resources, S.W. and M.W.; data curation, L.S., C.B., S.W., M.W., J.C.T. and L.T.; writing-original draft preparation, L.S., S.W., C.B., R.P., M.W. and P.V.; writing-review and editing, L.S., C.B., S.W., R.P., J.C.T., M.W., L.T. and P.V.; visualization, L.S., C.B. and R.P.; supervision, S.W., M.W. and J.C.T.; project administration, L.S., S.W. and M.W.; funding acquisition, S.W., L.S., M.W., P.V., J.C.T. and L.T. All authors have read and agreed to the published version of the manuscript.

Funding: This research was supported via collaboration by the University of Portsmouth (L.S. and M.W.), NIWA Taihoro Nukurangi Strategic Science Investment Fund Project No: CARH2206 (S.W. C.B. and R.P.), the Samoa Ministry of Natural Resources and Environment Internal Projects FY2122 (J.C.T. and L.T.), and GNS Te Pu Ao National Earthquake Information Database (P.V.). The APC was funded by NIWA Taihoro Nukurangi Project No: CARH2206.

Institutional Review Board Statement: Not Applicable.

Informed Consent Statement: Not Applicable.

Data Availability Statement: Baseline topography, bathymetry and exposure datasets used in this study as well as raw results are accessible via formal request to the Samoa Ministry of Natural Resources and Environment. The BG-Flood hydrodynamics modelling software is available on the GitHub: https://github.com/CyprienBosserelle/BG_Flood, and the RiskScape multi-hazard impacts modelling software is available at: https://riskscape.org.nz/.

Conflicts of Interest: The authors declare no conflict of interest.

\section{References}

1. Shultz, J.M.; Cohen, M.A.; Hermosilla, S.; Espinel, Z.; McLean, A. Disaster Risk Reduction and Sustainable Development for Small Island Developing States. Disaster Health 2016, 3, 32-44, doi:10.1080/21665044.2016.1173443.

2. Martyr-Koller, R.; Thomas, A.; Schleussner, C-F.; Nauels, A.; Lissner, T. Loss and damage implications of sea-level rise on Small Island Developing States. Current Opinion in Environmental Sustainability 2021, 50, 245-259. doi:10.1016/j.cosust.2021.05.001.

3. Williams, S.; Paulik, R.; Weaving, R.; Bosserelle, C.; Chan Ting, J.; Wall, K.; Simi, T.; Scheele, F. Multiscale Quantification of Tsunami Hazard Exposure in a Pacific Small Island Developing State: The Case of Samoa. GeoHazards 2021, 2, 63-79, https://doi.org/10.3390/geohazards2020004.

4. Pararas-Carayannis, G.; Dong, B. Catalog of Tsunamis in the Samoan Islands; International Tsunami Information Center: Honolulu, HA, USA, 1980.

5. Goff, J.; Dominey-Howes, D. The 2009 South Pacific Tsunami. Earth-Sci. Rev. 2011, 107. doi:10.1016/j.earscirev.2011.03.006.

6. Gusman, A.R.; Roger, J. Hunga Tonga - Hunga Ha'apai volcano-induced sea level oscillations and tsunami simulations. GNS Science webpage, 2022. Available online: https://doi.org/10.21420/DYKJ-RK41 (accessed on 28 January 2022).

7. Klein, A. Tongan volcano erupts. New Scientist 2022, 253(3370), 7, doi:10.1016/S0262-4079(22)00074-4.

8. Lavigne, F.; Morin, J.; Wassmer, P.; Weller, O.; Kula, T.; Maea, A.V.; Kelfoun, K.; Mokadem, F.; Paris, R.; Malawani, M.N.; et al. Bridging Legends and Science: Field Evidence of a Large Tsunami that Affected the Kingdom of Tonga in the 15th Century. Front. Earth Sci. 2021, 9, 748755, doi:10.3389/feart.2021.748755.

9. Hart, S.R.; Coetzee, M.; Workman, R.K.; Blusztajn, J.; Johnson, K.T.M.; Sinton, J.M.; Steinberger, B.; Hawkins, J.W. Genesis of the Western Samoa seamount province: age, geochemical fingerprint and tectonics. Earth and Planetary Science Letters 2004, 227(1-2), 37-56, doi:10.1016/j.epsl.2004.08.005.

10. Koppers, A.A.P.; Russell, J.; Jackson, M.G.; Konter, J.; Staudigel, H.; Hart, S.R. Samoa reinstated as a primary hotspot trail. Geology 2008, 36(6), 435-438, doi:10.1130/G24630A.1.

11. Koppers, A.A.P.; Russell, J.A.; Roberts, J.; Jackson, M.G.; Konter, J.G.; Wright, D.J.; Staudigel, H.; Hart, S.R. Age systematics of two young en-echelon Samoan volcanic trails. Geochem. Geophys. Geosyst. 2011, 12, Q07025, doi:10.1029/2010GC003438.

12. Kear, D.; Wood, B.L. The Geology and Hydrology of Western Samoa. New Zealand Geological Survey Bulletin No. 63. New Zealand Depart of Scientific and Industrial Research, Wellington, New Zealand, 1959.

13. Samoa Bureau of Statistics - Population \& Demographic Indicator Summary. Available online: https://www.sbs.gov.ws/population (accessed on 28 October 2021).

14. Angenheister, G.G. Geschichte des Samoa-Observatoriums von 1902 bis 1921. In Zur Geschichte der Geophysik. Springer-Verlag, Berlin, Germany, 1974, pp. 43-66. [History of the Samoan Observatory from 1902 to 1921 (translated from German by W.I. Reilly in 1978). 36 p.

15. Hatherton, T. Geophysics division, DSIR 1951-1976: an account of geophysical studies in the Department of Scientific and Industrial Research. Department of Scientific and Industrial Research, Wellington, New Zealand, 1980, 45 p. 
16. Tomlinson L.A. Observatories In New Zealand And The South Pacific. In Gubbins D.; Herrero-Bervera E. (eds). Encyclopedia of Geomagnetism and Paleomagnetism, Springer, Dordrecht. https://doi.org/10.1007/978-1-4020-4423-6_242.

17. Angenheister, G. Vier Erdbeben und Flutwellen im Pazifischen Ozean, beobachtet am Samoa- Observatorium, 1917- 1919. Nachrichten von der Königlichen Gesellschaft der Wissenschaft zu Göttingen, Mathematisch-Physische Klasse 1920, 201-204, https://eudml.org/doc/59086.

18. Németh, K.; Cronin, S.J. Volcanic structures and oral traditions of volcanism of Western Samoa (SW Pacific) and their implications for hazard education. Journal of Volcanology and Geothermal Research 2009, 186(3-4), 223-237, https://doi.org/10.1016/j.jvolgeores.2009.06.010.

19. Okal, E.A.; Fritz, H.M.; Synolakis, C.E.; Borrero, J.C.; Weiss, R.; Lynett, P.J.; Titov, V.V.; Foteinis, S.; Jaffe, B.E.; Liu, P.L.-F.; et al. Field Survey of the Samoa Tsunami of 29 September 2009. Seism. Res. Lett. 2010, 81, 577-591, doi:10.1785/gssrl.81.4.577.

20. Bosserelle, C.; Williams, S.; Cheung, K.F.; Lay, T.; Yamazaki, Y.; Simi, T.; Roeber, V.; Lane, E.; Paulik, R.; Simanu, L. Effects of Source Faulting and Fringing Reefs on the 2009 South Pacific Tsunami Inundation in Southeast Upolu, Samoa. J. Geophys. Res. Ocean. 2020, 125, doi:10.1029/2020jc016537.

21. Lay, T.; Ye, L.; Wu, Z.; Kanamori, H. Macrofracturing of Oceanic Lithosphere in Complex Large Earthquake Sequences. J. Geophys. Res. Solid Earth 2020, 125, 125, doi:10.1029/2020jb020137.

22. Kanamori, H. Importance of Historical Seismograms for Geophysical Research. In Historical seismograms and earthquakes of the world. Academic Press, San Diego, California, USA, 1988, pp 16-33. ISBN 9780124408708. https://resolver.caltech.edu/CaltechAUTHORS:20141216-125156671.

23. Engdahl, E.; Villasenor, A. 41 Global seismicity: 1900-1999. International Geophysics 2002, 81, doi:10.1016/S0074-6142(02)80244-3.

24. NCEI/WDS Global Significant Earthquake Database, 2150 BC to Present. Available online: https://www.ncei.noaa.gov/access/metadata/landing-page/bin/iso?id=gov.noaa.ngdc.mgg.hazards:G012153; view=iso (accessed on 20 January 2021).

25. Okal, E.A.; Borrero, J.C.; Chagué-Goff, C. Tsunamigenic predecessors to the 2009 Samoa earthquake. Earth-Sci. Rev. 2011, 107, 128-140, doi:10.1016/j.earscirev.2010.12.007.

26. Williams, S.; Titimaea, A.; Bosserelle, C.; Simanu, L.; Prasetya, G. Reassessment of Long-Term Tsunami Hazards in Samoa Based on Sedimentary Signatures. Geosciences 2020, 10, 481, doi:10.3390/geosciences10120481.

27. Samoa 1917 Earthquake, search results. Available online: https://paperspast.natlib.govt.nz/newspapers?items_per_page=10\&snippet=true\&query=earthquake+samoa (accessed on 1 December 2021).

28. Significant Earthquake Information, 1917 Earthquake - Samoa Islands. Available online: https://www.ngdc.noaa.gov/hazel/view/hazards/earthquake/event-more-info/3087 (accessed on 13 December 2021)

29. Vacondio, R.; Palù, A.; Ferrari, A.; Mignosa, P.; Aureli, F.; Dazzi, S. A non-uniform efficient grid type for GPU-parallel Shallow Water Equations models, Environ. Modell. Softw. 2017, 88, 119-137, doi:10.1016/j.envsoft.2016.11.012.

30. Okada, Y. Surface deformation due to shear and tensile faults in a half space. Bull. Seismol. Soc. Am. 1985, 75(4), 1135-1154, https://doi.org/10.1785/BSSA0750041135.

31. Reese, S.; Bradley, B.A.; Bind, J.; Smart, G.; Power, W.; Sturman, J. Empirical building fragilities from observed damage in the 2009 South Pacific tsunami. Earth-Sci. Rev. 2011, 107, 156-173, doi:10.1016/j.earscirev.2011.01.009.

32. Tarbotton, C.; Dall'Osso, F.; Dominey-Howes, D.; Goff, J. The use of empirical vulnerability functions to assess the response of buildings to tsunami impact: Comparative review and summary of best practice. Earth-Sci. Rev. 2015, 142, 120-134, https://doi.org/10.1016/j.earscirev.2015.01.002.

33. Paulik, R.; Horspool, N.; Woods, R.; Griffiths, N.; Beale, T.; Magill, C.; Wild, A.; Popovich, B.; Walbran, G.; Garlick, R. RiskScape: A flexible multi-hazard risk modelling engine. Research Square 2022, Preprint (Version No.1), doi:10.21203/rs.3.rs-1123016/v1.

34. World Bank. Population, total - Samoa. Available online: https://data.worldbank.org/indicator/SP.POP.TOTL?locations=WS (accessed on 10 December 2021).

35. Rahiman, T.; Pettinga, J.; Watts, P. The source mechanism and numerical modelling of the 1953 Suva tsunami, Fiji. Marine Geology 2007, 237, 55-70, doi:10.1016/j.margeo.2006.10.036.

36. Code, B. A secret pyramid consumed by the jungle. January 2020. Available online: https://www.bbc.com/travel/article/20200109-a-secret-pyramid-consumed-by-the-jungle (accessed on 24 September 2021). 